\title{
Gender, nutrition- and climate-smart food production: Opportunities and trade-offs
}

\author{
Tina Désirée Beuchelt • Lone Badstue
}

Received: 19 June 2013 / Accepted: 31 July 2013 /Published online: 18 August 2013

(C) The Author(s) 2013. This article is published with open access at Springerlink.com

\begin{abstract}
Future food and nutrition security is threatened by climate change, overexploitation of natural resources and pervasive social inequalities. Promising solutions are often technology-focused and not necessarily developed considering gender and social disparities. This paper addresses issues of gender and human development opportunities and tradeoffs related to promoting improved technologies for agricultural development. We examined these aspects for conservation agriculture (CA) as part of a cropping system with nutrition- and climate-smart potential. The paper is based on a literature review and field experiences from Zambia and Mexico. Findings point up situations where the promotion of CA for smallholders in developing countries may have undesired effects from gender and human development perspectives, specifically relating to drudgery, nutrition and food security, residue use, assets, mechanization and extension. The direction and magnitude of potential trade-offs depend on the local context and the specific intervention. The analysis is followed by a discussion of opportunities and pathways for mitigating the trade-offs, including gender transformative approaches; engagement with alternative or non-traditional partners with different but complementary perspectives and strengths; "smart" combinations of technologies and approaches; and policies for inclusive development.
\end{abstract}

Keywords Trade-offs · Gender and social equity .

Agriculture $\cdot$ Conservation agriculture $\cdot$ Technology diffusion

T. D. Beuchelt $(\varangle) \cdot$ L. Badstue

Socioeconomics Program, CIMMYT, Km 45 Carretera

Mexico-Veracruz, CP 56130 El Batan, Texcoco, Mexico

e-mail: t.beuchelt@cgiar.org

L. Badstue

e-mail: L.Badstue@cgiar.org

\section{Introduction}

Yield gains in agriculture over the last 50 years have been outstanding (FAO 2012), and overall world food production is sufficient to feed the current world population. Despite this, nearly 900 million people still go hungry, while the number of malnourished is estimated at two billion (FAO et al. 2012; FAO 2013). Further growth in food production helps to increase food availability but does not necessarily translate into enhanced food security among the poor, nor does it foster human development.

Malnutrition is a health threat especially affecting poor women and children (FAO 2010). The amount of food produced and available in a farm household does not implicitly relate to food quality, nutritional value, or diversity of household members' diets. As documented by Berti et al. (2004) many agricultural development interventions, including home gardening, livestock, mixed garden and livestock, cash cropping and irrigation, have indeed increased food production but have not necessarily led to improvements in the nutritional status of target populations. Thus, an integrated approach linking agricultural production and human nutrition is needed (Lemke and Bellows 2011).

The concept of nutrition-sensitive or nutrition-smart agriculture has recently been taken up by more development organizations and figures more prominently in policies (for example, World Bank 2007). Nutrition-sensitive agriculture "involves the design and adoption of cropping and farming systems which can provide agricultural remedies to the prevailing nutritional maladies" such as hidden hunger, malnutrition or transient hunger (Swaminathan 2012 , p. 2 f.). Nutrition-smart agriculture relates to a move from a crop- or livestock-specific viewpoint to a farming systems perspective that includes the farming household. 
By the same token, the farming household should not be assumed to operate as a unified economic entity. Rather, gender-specific intra-household resource and labour exchanges, negotiations and allocations exist (Alderman et al. 1995). Gender ${ }^{1}$ aspects relate directly and critically to women's and men's roles and responsibilities in the farming household and to decisions about allocating resources or adopting technologies in farming systems. Priority setting is not necessarily shared among household members: resources are usually allocated according to the priorities of the most powerful household member, in most cases, a male (Ponniah et al. 2008).

Human development has to take place "in a world that is marked, on the one hand, by enormous inequities in contemporary living conditions, and on the other, by real threats to the prospects of human life in the future" (Anand and Sen 2000, p. 2029). Threats to future food security include climate change, soil degradation and overexploitation of natural resources. Human development can therefore be considered part and parcel of sustainable development, which in turn, has to find the equilibrium and equity between the needs of present and future generations (see also the Brundtland Report, WCED 1987).

Large gender inequalities in access to and control over resources constitute a major challenge for sustainable and inclusive development in agriculture, with efficiency and cost implications for the sector that impact the broader economy and society (FAO 2011). Research has shown that changes in the distribution of inputs and/or control over resources between men and women farmers can significantly increase productivity, food and nutrition security, and education outcomes (Alderman et al. 1995; Meinzen-Dick et al. 2011; Quisumbing and Maluccio 2000; World Bank 2009).

In summary, research and development for agriculture and for food-based approaches to improved nutrition face the challenges of (i) enhancing the food and nutrition security of poor women, men, girls and boys, (ii) increasing gender and social equity and decreasing poverty as part of human development and (iii) being socio-economically and environmentally sustainable.

Solutions often focus on technological innovations, but do not necessarily consider social disparities and often affect women and men differently. Research has shown that individual agricultural technologies or technology packages can affect women and men differently within households and communities. As noted by Milder et al. (2011, p.25), conservation

\footnotetext{
${ }^{1}$ We use the term gender to refer to the socially constructed different roles, rights, and responsibilities of men and women and the relations between them. Women and men, and their relations, are defined in different ways in different societies that are influenced by historical, religious, economic, and cultural realities. The roles and relations between women and men are dynamic; they do change over time and also depend on age, class, race, ethnicity, social and marital status (Doss 2001).
}

agriculture (CA) interventions, "are not always genderneutral in terms of labor requirements, empowerment, or economic benefits and costs" (see also Baudron et al. 2009; Erenstein 2003; Nyanga et al. 2012). Yet, explicit discussion of these and related trade-offs is limited and there is little indepth analysis of conservation agriculture from a gender and social equity perspective.

This research paper first introduces the issue of potential trade-offs and opportunities of nutrition- and climate-smart agriculture from the gender and human development perspectives, and posits a set of categories for identifying those tradeoffs and opportunities. Second, we use conservation agriculture - a management practice with nutrition- and climatesmart characteristics - as an analytical case to explore whether and to what degree such trade-offs apply. Third, we identify opportunities and pathways to enhance gender equity by way of nutrition- and climate-smart agriculture and propose a conceptual model for this. We also explain the urgent need for agricultural research and development interventions to embrace a more systems-oriented and interdisciplinary approach that specifically addresses gender and social inequality.

\section{Potential trade-offs of agricultural technologies from a gender and social perspective}

The objectives of agricultural research for development interventions must be clearly and explicitly defined, whether they concern economic development (e.g., increasing income through higher yields or value-chain development), human development (e.g., home-gardens for better nutrition), or mainly environmental sustainability (e.g., carbon sequestration in permaculture). While agricultural and economic development can lead to income growth, the latter is only a means to reach human development but not its objective in itself (Anand and Sen 2000). This distinction - that the objective of development is not the yield or income as such but the expansion of possibilities in life - is important in relation to agricultural technology development from a gender and social perspective.

Agricultural technologies can help reduce labour and drudgery, diminish physical strain, free up time for other activities, and/or lead to increasing income and control over outputs. However, when a new agricultural technology is characterised as labour-saving, "it is important to determine whose labor is saved and at what point during the agricultural season" (Doss 2001, p. 2080).

Several studies have shown that women's labour burden can increase with new technologies, such as when women take on additional tasks or when current tasks become more burdensome, for instance when applying fertilizer leads to the need for more weeding or more output to process - both tasks 
often done by women (Doss 2001). Along similar lines, Berti et al. (2004) point to unintended negative impacts on childcare: "an intervention that increases the amount of time women work in the field without considering childcare may improve food availability and diet, but hurt child welfare" (Berti et al. 2004, p. 605). In other words, interventions that focus narrowly on agricultural innovations and production increases may involve unintended livelihood trade-offs, such as malnourishment, anaemia or morbidity (Berti et al. 2004), which must be weighed against potential benefits. In the end, how the net effects look for a woman must be decided by her alone (Doss 2001).

Women farmers often lose control over the market niches, resources and products they traditionally manage, once those resources and products become lucrative: men will often take over production and marketing, even of traditional women's crops (Berti et al. 2004; Doss 2001; Momsen 2010; World Bank 2009). Thus, what appears as progress or development from one perspective actually brings negative side effects, increasing women's dependence and diminishing their income opportunities, power, and traditional status (Momsen 2010; Moser 1993).

The potential positive or negative effects of improved agricultural technologies may be very context specific, depending on cultural and social circumstances: see Paris and Pingali (1996) on the gendered impact of a new laboursaving technology. The introduction of a mechanical thresher in the Philippines reduced labour for both men and women, as threshing is much faster. Farmers were thus able to grow a second rice crop which benefitted women as it increased their employment opportunities in transplanting, weeding and harvesting. The benefits outweighed the reduced labour demand for threshing. Conversely, in Bangladesh the introduction of a mechanical thresher affected poor and landless women negatively because it replaced their work as threshers. As cultural restrictions prevented these women from leaving their homestead, they could not look for alternative employment opportunities and thus lost an important income source (Paris and Pingali 1996). In Vietnam, plastic row/drum seeder technologies were promoted due to their advantages over the traditional transplanting or broadcasting method of rice production. Paris and Truong Thi Ngoc Chi (2005) showed that the farmers who adopted the row seeders were those who had good access to extension agents and relatively better educated wives. However, adoption of the new seeders eliminated the important wage labour and income opportunity of rice transplanting for more than half the women in poor farming households, who previously worked as agricultural wage labourers.

Another example of unfavourable effects of an agricultural innovation intervention is the promotion of maize-bean intercropping in Zambia in a context where, traditionally, maize - and especially high-yielding varieties - is controlled by men, whereas beans are considered women's crops. Women were reluctant to adopt the intercropping system because they feared that they would lose their control over bean cropping and their entitlements to the beans. Specifically, they worried that household food consumption would suffer if their husbands sold the beans for cash and used the income either for themselves or to purchase non-food items (Feldstein 2000 cited by Charman 2008). Women thus resisted adoption and the chance to improve yields, increase soil quality and contribute to sustainability was missed.

Male and female farmers often prefer different crops or crop varieties. Several studies have shown that women and men value maize traits differently and prefer different trait combinations, relating to differences in the intended consumption objective: whether for market, for own consumption, for food security, for special dishes, or for feed (Badstue 2006; Bellon 1996; Bellon et al. 2003; Deere 2005; Hellin et al. 2010). Men often prefer high-yielding varieties and value the potential to sell surplus production. Women's reproductive roles $^{2}$ tend to influence their priorities towards food security and varieties that are palatable, nutritious, and meet processing and storing requirements (Badstue 2006; Bellon et al. 2003; Doss 2001). In both Mexico and southern Africa, women farmers' varietal preferences are also linked to their productive role and income generation from the artisanal processing and sale of traditional maize products (Badstue 2006; Bellon et al. 2003; Doss 2001). In yet another case, women explained that, despite their superior yields, improved maize varieties often took longer to cook, requiring more firewood and labour than farmer varieties (Hellin et al. 2010).

As these cases illustrate, it is not necessarily possible to predict how the introduction of new agricultural technologies may affect the patterns of labour, resource and land allocation between men and women. Neither is it possible to say how this may influence whether a new technology is adopted or not, and who will benefit or lose from adoption. Both intended and unintended impacts can occur at the individual, household and/or community levels. The challenge of estimating potential consequences relates both to gender considerations (Doss 2001) and broader aspects of human and sustainable development.

\footnotetext{
${ }^{2}$ Women in rural areas usually have triple roles: reproductive, productive, and community management (Momsen 2010; Moser 1993). The reproductive role refers to childcare and housework. The productive role can vary from subsistence food production, petty trade, to involvement in paid, formal employment. The community role refers to women's activities within the community, maintaining social networks and relations as well as the provision of items for collective consumption such as contributions to religious festivals (Moser 1993). The community role is often overseen and not recognized even though it is a fundamental part of the household's security and risk-management net (Beuchelt 2008; Fischer et al. 2010).
} 
As part of the food system, agricultural production, processing and marketing can contribute to food and nutrition security, as well as to health, decent livelihoods, gender equity, safe working conditions, and participation in political and cultural life (Anderson 2008). Food security is only achieved when each individual has physical and economic access to adequate food or to the means to procure such food (FAO 1996). ${ }^{3}$ Access to food and a nutritious diet can be achieved through people's own production of food, through incomegenerating activities (within or outside agriculture), through a mix of both or, if otherwise not possible, through special social programs (Beuchelt and Virchow 2012; see also the General Comment 12 of the UN-CESCR 1999). ${ }^{4}$

In Fig. 1 below, we present five analytical categories to identify, from the gender and human development perspectives, possible opportunities and trade-offs for nutrition- and climatesmart agricultural technologies (Fig. 1). The categories are ones where gender and social differences can play important roles: food and nutrition security as well as diversity; health aspects; access to information and technology; resources and labour; income, marketing and value chains. The definitions of the categories derive from a review of the literature on human rights-based approaches to development, particularly for agriculture, nutrition and women (for example Anderson 2008; Cornwall and Nyamu-Musembi 2004; FAO 1998; Lemke and Bellows 2011; Rae 2008; Socorro Diokno 2013).

The effects of technologies and interventions are assumed to vary among individuals in a household, depending on socio-cultural context, gender, age, religion, skills, abilities, social relations including kinship ties, and economic and social status. Gender is a determining factor in defining who does what, who has what, who decides, and who has power (UNICEF 2011). The gender perspective emphasizes differences between male and female household members, particularly with regard to the division of labour, access to and control over resources (natural, physical and financial), as well as access to information, decision-making power, mobility and social interaction (CCAFS and FAO 2012).

For each category, these factors need to be considered in relation to potential opportunities and trade-offs, as well as who benefits and who might be negatively affected. Opportunities and trade-offs may also occur among categories: mechanization can reduce drudgery for women and children,

\footnotetext{
$\overline{3}$ The official FAO (1996) definition of food security is: "Food security exists when all people, at all times, have physical and economic access to sufficient, safe and nutritious food to meet their dietary needs and food preferences for an active and healthy life."

${ }^{4}$ For those who cannot achieve food security through either own production or income-generation, due for example to natural disasters or conflicts, the issue of social protection and special programs is relevant.
}

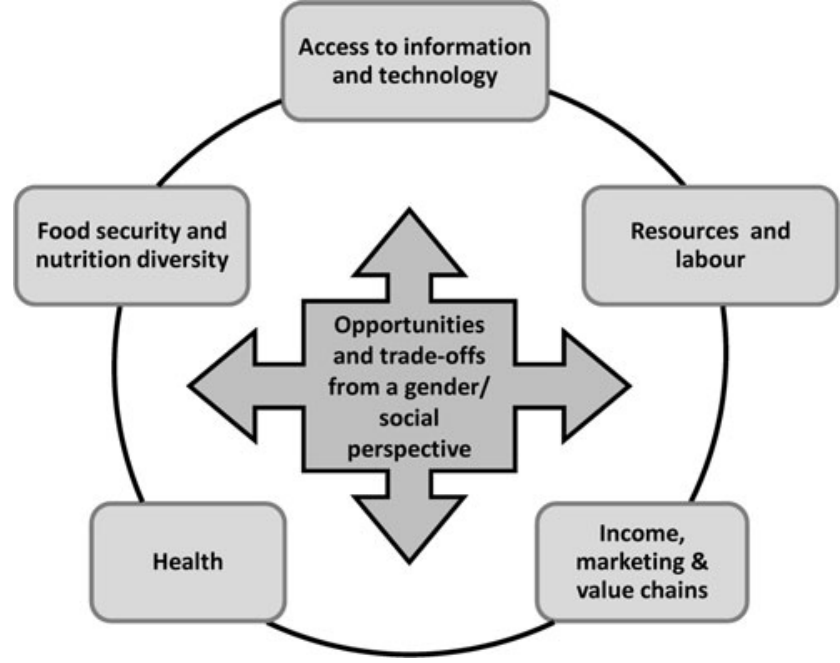

Fig. 1 Analytical categories for identifying potential gender and social equity trade-offs or opportunities related to agricultural technologies

which in turn can improve health and free up time for other activities and for children's schooling. On the other hand, it may also mean that rural poor who previously depended on day labour could lose an important income opportunity. Identifying gender- or social equity trade-offs, in itself, may lead to opportunities, i.e. the development of solutions to the specific trade-off in question, or, lead to the discovery of complementary measures that can enhance the overall potential for positive impacts of the particular intervention.

\section{The case of conservation agriculture from the gender and social perspectives}

There is growing interest in sustainable agricultural management practices that contribute to food security, counteract soil degradation and improve climate change resilience. Conservation agriculture (CA) is an example of intenselyresearched and globally promoted sustainable technology (Derpsch et al. 2010; Erenstein et al. 2012; Giller et al. 2009; Hobbs 2007; Hobbs et al. 2008; Kassam et al. 2009; Knowler and Bradshaw 2007; Nyanga et al. 2012; Valbuena et al. 2012; Wall 2007). Evidence shows that CA can enhance soil health, contribute to higher and more stable yields, and reduce production costs (Erenstein et al. 2012; Govaerts et al. 2005; Kassam et al. 2009). The aforementioned benefits contribute to medium - and longer-term sustainable development and can be observed after 10-12 years, if not sooner (Govaerts et al. 2005, 2009).

The three key components of conservation agriculture, as described by Kassam et al. (2009), are: (i) maintaining a permanent organic soil cover, either from cover crops, intercrops and/or from the mulch provided by residues of the previous crop; (ii) minimizing soil disturbance from tillage 
and cultural operations; (iii) diversifying crop rotations, sequences and associations. The potential for CA to contribute to nutrition-sensitive agriculture is particularly related to intercropping and crop rotation, for instance with proteinrich legumes. These practices can enhance the diversity of food crops grown, and therefore, in principle, also the diet diversity of the farmer and her household.

Conservation agriculture entails complex management practices and requires a significant change from conventional practices. It is knowledge-intensive and its acquisition often comes with high (opportunity) costs for smallholders (Wall 2007). These include the costs of moving to and adapting CA practices for specific farming systems, as well as having access to inputs, markets, machinery, credit, and information (Erenstein et al. 2012; Wall 2007). Depending on the level of mechanization and inputs used, additional challenges can relate to the availability of and demand for labour (Baudron et al. 2007; Nyanga et al. 2012) and to increases in weeds and pests (Erenstein et al. 2012; Wall 2007). Use of crop residues to cover soils often competes with their traditional uses in smallholder systems for fuel, for thatching, or for livestock fodder, especially in areas with long dry periods and limited biomass availability (Erenstein et al. 2012; Hellin et al. 2013; Kassam et al. 2009; Wall 2007). The improvement of the physical condition of soil and reduction of its erosion owing to CA, resulting in better crops (Govaerts et al. 2009) can lead to trade-offs between human development and environmental benefits. As pointed out by Baudron et al. (2007), despite the promotion of $\mathrm{CA}$ in developing countries for more than 20 years, there is still a lack of sound socio-economic studies regarding its profitability and returns to male and female labour and the land owned or managed by each.

Although women play a key role in agriculture worldwide, cropping and farming system research and development have paid little attention to gender issues so far. In their review of research on the adoption of conservation agriculture, Knowler and Bradshaw (2007) cite gender as an important factor. In the rest of this section, we discuss gender and social considerations associated with $\mathrm{CA}$, as well as their linkages to food and nutrition security. The categories from Fig. 1 are treated together, given that trade-offs can relate to several categories at the same time; for example, the use of herbicides has potential trade-offs in all five categories.

\section{Resources, labour and access to information and technology}

In many countries of sub-Saharan Africa, conservation agriculture is promoted via the establishment of hoed planting basins or the introduction of strip tillage, using for example the "Magoye" ripper, an animal-drawn tool to prepare land. In Zambia, a special tool known as the chaka hoe is recommended to facilitate digging planting basins in hardened, dry season soils. However, Zambian female farmers found that the use of the chaka hoes "was exhausting and reduced their performance in other household chores" (Nyanga et al. 2012, p. 11), implying trade-offs with women's reproductive role. Nyanga et al. (2012) also found that digging planting basins increased women and children's workloads in initial years. ${ }^{5}$

Manual weeding is a women's task in many developing countries. In cases where CA systems are based on manual weeding, the labour burden of women and men can actually increase to an unsustainable level (Giller et al. 2009; Nyanga et al. 2012). With the introduction of herbicides, labour drudgery for manual weeding will be reduced, especially for women (Nyanga et al. 2012). This can be of great importance and help to smallholders when they face labour constraints. However, it may likewise reduce the need for hired labour, making life much more difficult for those who depend on this income source and do not have other opportunities. Another problem in remote areas is that female or poor subsistence farmers cannot afford or access herbicide or equipment such as sprayers to apply it (Valbuena et al. 2012).

The mechanization often related to CA-for example direct seeders - can significantly reduce drudgery and improve efficiency, with considerable benefits for farm household members. Yet, as noted above, labour-saving technologies for land preparation, sowing, weeding or threshing can also reduce traditional work and income opportunities for groups such as poor women or the landless. In some contexts cultural norms may inhibit women from using certain machinery. With increasing mechanization, women's opportunities in agriculture have often been reduced (Momsen 2010; Moser 1993). If machinery needs to be purchased, be it by individuals or groups, the high investment can reduce liquidity and the money available for other household needs and even put farmers in debt.

Given the high levels of migration from rural communities in many developing countries, labour availability for agriculture is a common constraint for smallholder farming (Hellin et al. 2010). Labour scarcities can sometimes favour CA adoption, but if $\mathrm{CA}$ is to be adopted by the wives of migrant men, its local adaptation needs to take into account female farming systems, resource endowments, land titling rights, and ability to use machinery. Furthermore, gender transformative approaches ${ }^{6}$ that seek to change rigid norms need to be incorporated in research, extension, and adaptation processes

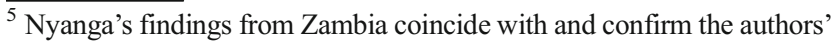
observations from Zambia, which are referred to in the next section.

${ }^{6}$ In our definition gender transformative approaches actively strive to examine, question, and change rigid gender norms and the imbalance of power as a means of achieving development objectives as well as meeting gender equity objectives. These research, programmatic and policy approaches challenge the distribution of resources and allocation of duties between men and women.
} 
to enable women to make decisions about technology uptake and implementation. However, poor farmers, especially females, are often disadvantaged in education and thus not targeted by extension systems; if they are to adopt CA at all, they require time to gain the necessary knowledge and skills.

Land tenure is a key issue because of the significant and longterm investments in soil improvement. Where land tenure is uncertain farmers may be reluctant to adopt CA, because they risk losing their investment if the land is reallocated or reclaimed by others. In a review of agricultural innovation and female farmers in Africa, Doss (2001) comments on women's lack of incentives to adopt soil management measures on their plots, because of the risk of losing access to the land and their investments. On-going research by CIMMYT and partners in Mexico, where many farmers rent land informally, show that when experimenting with new technologies including CA, farmers often prefer to do so on a rented plot. If they decide to adopt, they will typically do so on their own land where they have secure control of their investment (Ramírez-López et al. 2013).

Regarding use of crop residues as permanent organic ground cover, this can have various trade-offs in farming systems where residues have multiple uses, such as feed in mixed crop-livestock systems, as fuel, or as construction material (Hellin et al. 2013). Where women collect firewood and crop residues are traditionally used for this purpose, claiming residues for ground cover can mean that women have to spend more time looking for fuel alternatives and can also increase pressure on resources such as trees or shrubs. Where women are responsible for feeding livestock, the loss of crop residues as a feed source is likely to increase women's time and effort in obtaining alternative feed. If this fails or fodder is scarce, animals may produce less or herd size will diminish, threatening incomes and food security.

Where customary free grazing after harvest is the norm, crop residues left for CA may be consumed by livestock and conflicts may ensue between CA adopters and pastoralists. A commonly suggested solution is to involve the community, explain the benefits of conservation agriculture, and change local institutions towards a prohibition of stubble grazing (Erenstein et al. 2012). But it is not clear how changes in local grazing practices may affect marginalized livestock holders and herders, including women, the old and the handicapped, who are often poor and completely dependent on free residues. Other common land resources, such as community pastures and forests, could be negatively impacted by restricting free grazing, with long-term implications for local food security and livelihoods.

\section{Food security, nutrition diversity and health}

In the case of the planting basins in Zambia, Nyanga et al. (2012) observed that intercropping and earlier planting as a result of land preparation during the dry season reduced the hunger period from 4 to 3 months. Diversifying cropping through rotations or intercrops for soil cover can increase food and nutrition diversity where this was not practised before. Typical crops used in intercropping systems are maize, beans and other pulses, pumpkins, okra, and cucumber.

An important argument for promotion and adoption of CA is the potential to increase future yields (Govaerts et al. 2005). However, yield increase benefits are not necessarily shared equally by all farm household members; men may reap the income and decide not to use it to increase household food consumption or nutrition diversity (World Bank 2009). Where women contribute significant labor but receive no additional income or benefits from cash crop yields, they and other household members may be worse off.

In intercropped systems, the application of herbicides can negatively affect the intercrops, especially when instructions of how to apply them are not fully understood or adequate products are not available. Both the findings of Nyanga et al. (2012) from Zambia and the authors' own observations from Mexico indicate that certain species of the naturally emerging flora within a field are traditionally used to enrich and complement diets, and are thus not considered to be weeds. Such wild plants may be used as vegetables and provide important micro-nutrient, calorie- or taste contributions to local diets, especially in the hunger season (Nyanga et al. 2012). In this context, the use of herbicides may impact negatively on household food security, diet diversity and, in some cases, women's or the household's income (see Nyanga et al. 2012). Thus, where the Zambian farmers in the study of Nyanga et al. (2012) declined the use of herbicide in order not to lose an important food source, women still paid the price as weeding is considered their responsibility: "Increased labour reduction through herbicide use implies an increased immediate risk of being food insecure [...] farmers opted not to use herbicides and women had to bear the cost of increased labour requirement" (Nyanga et al. 2012, p. 15).

Furthermore, improperly managed herbicides can directly harm the health of household members. Recent research also points out that herbicides like glyphosate or atrazine can contaminate ground water and thus affect human and animal health in rural areas (Ackerman 2007; Hayes et al. 2011; Kettles et al. 1997; Sanchís et al. 2012).

Derived from the issues highlighted above, Table 1 presents a series of questions to help identify potential trade-offs of CA interventions. It is organised along the five categories used in Fig. 1. The table can serve as a checklist for researchers, development practitioners, and policy-makers to explore the potential effects of CA, ideally together with local stakeholders.

As shown, CA can imply diverse trade-offs from a gender perspective. Which trade-offs occur in practice depend on the specific context, the farming system, and prevailing gender 
Table 1 Guiding questions to explore potential effects of CA on women and men in smallholder agricultural systems

Categories Questions to explore potential effects of CA on women and men

Food security and nutrition diversity

Health

Access to information and technology

Resources and labour

Income, marketing and value chains
- Is there a potential for yield increase? Who benefits from this?

-Will crop rotation/intercropping affect nutrition diversity and food security? How?

-Will herbicides and mulch layers affect traditional intercrops and wild vegetables (often planted/controlled by women)? If so, will this affect nutrition diversity, food security or increase gender disparities?

- Does anyone depend on crop residues? Is there a risk that livestock farmers will be negatively affected if residues are retained for mulching?

-Will food or cash crops be grown? If cash crops are used, who controls the income and is it allocated to household food and health expenditure?

-Will yield increase or crop diversification improve nutrition? How? Will household members benefit equally? How will this lead to better health?

- Is there a risk that herbicide use may lead to health hazards? How? Who will be affected?

-What are the effects of increased labour requirements on household members, especially women and children? Is there the risk that e.g. children's welfare and nutrition may be negatively affected?

- Do extension services target women and men equally? Are the extension services gender responsive, i.e. do they consider women's special needs?

- Will the understanding of agricultural management practices be increased? Whose understanding? Is there a risk this may increase gender disparities? Who will be targeted and who will benefit?

-Will other sustainable agricultural technologies be discussed as alternatives to CA?

-What are women's specific needs and constraints in the farming system? Are these taken into account? Is there a risk that women may be excluded from the use and benefits of mechanization due to prevailing gender norms?

-Who will benefit from reduced drudgery due to mechanization and/or reduced tilling?

-Will labour requirements for land preparation increase in the short term? Who will be expected to do this?

- Whose labour will be reduced when herbicides are introduced? To whom is it a benefit?

- Who can lose out from reduction in labour requirements?

- Are herbicides available and affordable? To whom? Who decides on herbicide use?

- Who has access to and control over land? Is there a risk that land improvement through CA can lead to loss of access to the land?

- Is there a risk that crop rotation/intercropping will lead to "men's crops" encroaching on female plots? Is there a risk that women may lose access to land or control of traditional "women's crops" and/or related income?

- Is there a risk that labour requirements to obtain alternative livestock feed or fuel will increase if residue availability is reduced? Who will be affected by this?

- Who benefits from and decides on the use of additional income or savings? Is there a risk that this may lead to an increase in gender disparities?

- Who is affected when wild plants can no longer be harvested and consumed or sold?

- Who, if anybody is affected when herbicides/mechanization replaces labour? Women or men? Do they have alternative income possibilities? What does it mean for their families and their food security?

-What are the effects when crop residues left in the field become private property?

How does this affect shepherds/livestock producers?

-What are the effects of investment in CA technologies on households' financial situations? norms. The impacts of a specific technology on certain social actors or in a particular setting can be entirely different for other social actors or in a different setting.

\section{Opportunities and pathways to enhance gender and social equity with nutrition- and climate-smart agriculture}

Having highlighted potential trade-offs around nutrition- and climate-smart technologies, the question remains as to how the trade-offs can be converted into opportunities and pathways for making agricultural technology development more equitable, more gender responsive and nutrition-smart. The ultimate goal is to reduce rural poverty, improve food security, human nutrition and health, and the sustainable management of the natural resource base, as envisioned in the CGIAR's four system-level outcomes (ISPC 2013).

Figure 2 illustrates the approach required to achieve nutrition- and climate-smart food production which contributes to human development with a gender and social equity 


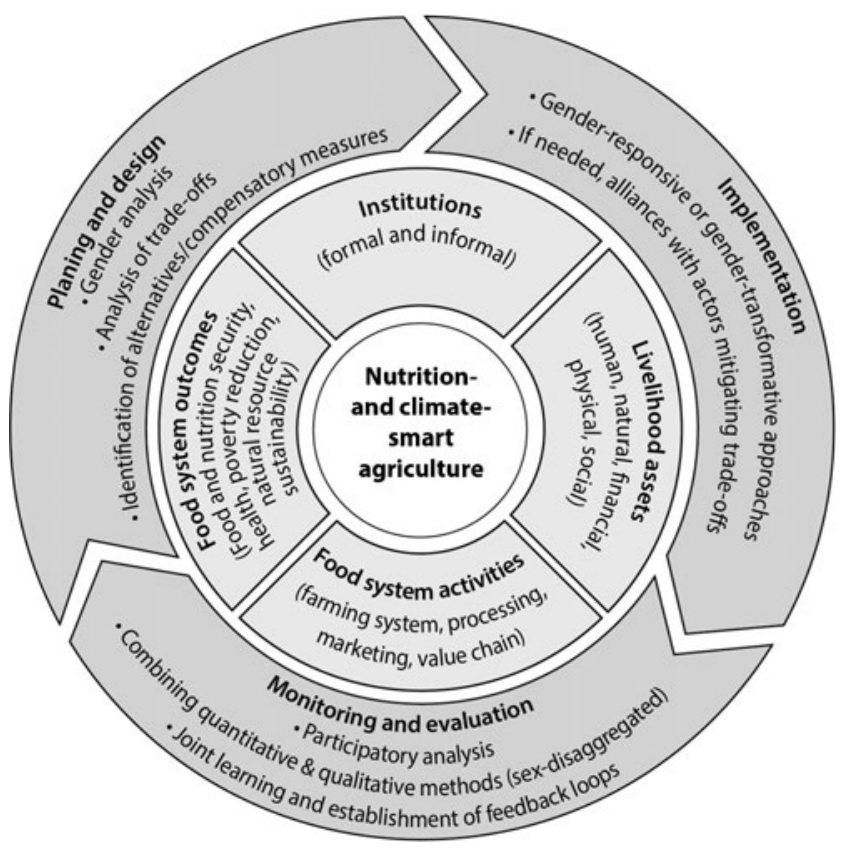

Fig. 2 Conceptual model for enhancing gender and social equity in nutrition- and climate-smart agriculture

perspective. The overall objective (nutrition- and climatesmart food production; in the centre) is surrounded by four components: livelihood assets, institutions, food system activities, and food system outcomes. The components reflect different impact pathway levels, but are not cast in a rigid, linear relationship.

The 'livelihood assets' component includes the human, natural, social, physical and financial capital needed for agricultural production, processing and marketing (DFID 1999). The 'food system activities' component includes the foodrelated activities undertaken in the farming system and value chains. The 'institutions' component includes formal institutions such as legislative frameworks and policies, as well as informal institutions - values, social relations and norms that shape beliefs and behaviours. The latter influence relationships between men and women. The 'food system outcomes' component comprises food and nutrition security, health, poverty reduction and natural resource sustainability. The four components are interrelated, the manner and extent depending on the specific intervention and context.

The findings presented so far suggest that fully achieving nutrition- and climate-smart agriculture requires a gender and social equity perspective for each component. This can be achieved at several stages in the research-, development project- or policy cycle, represented in the elements of the outer circle of Fig. 2. The outer circle refers to the project cycle (European Commission 1999). For the purpose of simplicity we focus here on the following components: (i) planning and design, (ii) implementation, and (iii) monitoring and evaluation.

\section{Planning and design phase}

At the planning and design stage, opportunities and trade-offs of agricultural interventions need to be assessed (for example, using the categories in Fig. 1 or the questions in Table 1) and include a sound gender analysis. This provides the opportunity to identify joint priorities together with relevant stakeholders, adjust research targeting and project design, and to devise context specific alternatives or ways to mitigate negative trade-offs, for instance by combining various technologies or approaches. For example, to enhance nutrition benefits, CA can be introduced together with legumes or biofortified crop varieties to increase protein or micronutrient availability. To compensate gender trade-offs, varieties which are of specific importance to women - say, for their processing or marketing qualities - can also be promoted. Gender transformative approaches can further foster benefit for both women and men.

Opportunity/trade-off assessments can also help identify implementation partners with appropriate and complementary skills and perspectives. For example, where CA mechanisation shows great promise for reducing labour input requirements and farmers' production costs, collaboration with alternative actors such as non-governmental organizations or special programs can mitigate negative impacts for landless workers who previously earned a living performing the tasks eliminated as part of CA.

\section{Implementation phase}

Male and female farmers usually have different extension needs and often female farmers are not able to comfortably voice their views, needs, and preferences or pose questions in a male-dominated context. In certain societies cultural norms and practices limit, or even prohibit, the interaction of male extension agents with women who are not their relatives. Gender responsive ${ }^{7}$ or gender transformative approaches can help ensure that both men and women are able to benefit from new technologies and can help foster changes in local gender norms and inequalities. For example, as documented by FriisHansen et al. (2012), farmer field schools, where women and men farmers learn together in mixed or separate groups with the help of an extension agent, have been shown to have positive impacts on household gender relations, including changes in the division of labour and decision-making, in gendered customs and traditions, in work ethics and in the general view of women and men.

\footnotetext{
${ }^{7}$ We define gender responsive approaches as designed to meet both women's and men's needs. These approaches ensure that both women and men will benefit and neither will be harmed by research, programs and policy, such as, for example, by exacerbating their work burdens.
} 
Gender transformative approaches seek to examine, question, and change gender norms, roles, and power imbalances. They are a means to achieve objectives such as improved livelihoods, gender equity and sustainability via nutrition- and climate-smart agriculture. They foster critical awareness of gender roles and relations between women and men; promote more genderequitable relationships; challenge the unequal distribution of resources and allocation of duties between men and women; or address the power relationships between different stakeholders and social actors (CGIAR Consortium 2012; USAID and IGWG 2011). The use of gender responsive, gender transformative or other approaches for mitigating social trade-offs may require adding special expertise to project teams.

\section{Monitoring and evaluation}

Monitoring is an integral part of project management and should be conducted throughout implementation to determine if an intervention is on track, to discover unexpected issues or effects, whether positive or negative, and to define corrective measures. During evaluation the degree to which the intervention has achieved what it set out to do is assessed. Ideally this should include the intervention's contribution to gender and social equity. Both monitoring and evaluation can involve participatory approaches that ensure representation of beneficiaries' and other stakeholders' views, offer opportunities for joint learning and reflection, and inform current and future interventions. A combination of quantitative and qualitative methods can document and explain changes observed during the intervention. To capture gender and social dimensions, data collection should be disaggregated by relevant categories, such as gender, age, and wealth.

Social change happens over time and often takes place in complex social realities, influenced by economic, cultural, agroecological and political factors. It is an ongoing effort that happens in small steps. Thus Fig. 2 reflects a reiterative complex dynamic between the interrelated components of the inner circle, which is associated with a process of continuous improvement.

Gender transformative approaches can be powerful means to stimulate awareness and change in systems where current extension and technological approaches alone have had limited effect with regards to adoption of the promoted technologies, reducing social inequalities and ensuring equitable benefit sharing between men and women. The following describes a successful example where nutrition- and climatesmart technologies were applied with the purpose of contributing to sustainable intensification, while at the same time addressing gender. ${ }^{8}$

\footnotetext{
${ }^{8}$ This example builds on a three-month fieldwork project which included participatory assessments of the promoted technologies, key informant interviews and a literature review.
}

\section{Gender transformative approaches and nutrition- and climate-smart technologies in Zambia}

The Zambian National Agricultural Sector Investment Program targeted core agricultural technologies and services such as new crop varieties, integrated pest management techniques, better crop management and conservation tillage/ agriculture, on-farm seed production, nutrition education, and technical capacity strengthening of the extension system. A participatory extension approach (PEA) was developed between the Ministry for Agriculture Food and Fisheries and NGO staff in 1992. The approach attempted to empower farmers in identifying their own problems and needs and to undertake actions to overcome those problems. It was soon felt that despite their high labour input in agricultural production, women were not well targeted by agricultural extension staff. Klos (2000) reported that women were scarcely represented in extension meetings and, if they attended, they were silent owing to societal norms. Extension activities were directed towards the male household heads, who would take all related decisions, often without passing the relevant information on to their wives. Despite the extension and intervention activities, agricultural production remained very low.

As a reaction to the shortcomings of the PEA, the GenderOriented Participatory Extension Approach (GPEA) was launched in 1993/4. Extension staff were trained to raise gender awareness among staff and target groups (Kürschner et al. 2000). They introduced a household or family approach to initiate a joint learning process amongst family members. The household approach is a non-confrontational and effective way of addressing gender issues. It aims to bring about changes in gender relations "from within" the household, rather than from outside the household (Bishop-Sambrook and Wonani 2008). As part of the approach, husbands, wives, and older children were invited to attend meetings and field demonstrations so that all members could understand and tackle problems as a unit. The family met together with the extension agent, participated in setting the household vision and action plan, and worked together during implementation and benefit sharing (Bishop-Sambrook and Wonani 2008).

Later on, a couple-approach was added to create awareness, to reflect and improve the gender relations and human relationships between couples, in families, and across the different social groups of the communities. This approach allows individuals to identify what they like and dislike in relation to gender roles and its causes, effects and possible solutions. Crop use, nutrition education, and cooking demonstrations were integrated into these workshops. An impact assessment of the GPEA showed that many things had changed for those who participated. For example, the relationships between men and women, their roles, access to and control over resources, decision-making, and division of labour and responsibilities had changed (Klos 2000; Kürschner 
et al. 2000). These changes positively affected the agricultural production of food crops, household food security and the well-being of the family. Through the introduction of legumes, the family had more access to protein-rich food and some cash through sales (Klos 2000).

Through the GPEA and household approach, women were empowered to make their own decisions in ways that did not create conflicts in their relationships. In addition they became used to active participation, could move around more freely, were allowed to keep their own income and were more involved in decision-making (Klos 2000; Kürschner et al. 2000). These changes had also led to an increase of responsibilities and burden for women while bringing at the same time new freedoms. This new balance of power was reached more easily in monogamous families, where only one husband and one wife had to compromise, than in polygamous families. Men accepted the change because they also benefitted from it; it meant that they could share the responsibilities and receive support from their wives, which reduced fighting in the family (Klos 2000). This example shows how sustainable intensification and gender can be addressed at the same time creating a win-win situation.

\section{Conclusions}

There are many positive characteristics of nutrition- and climate-smart agricultural technologies, including yield increases, crop diversification, improvements in soil quality, and labour savings. The global or overall effects of a technology are often positive, but the resulting benefits may be shared in different ways by different groups, for example between women and men. In the worst case, interventions may even increase gender and social disparities.

In the above we presented a set of analytical categories (Fig. 1), which can help the assessment of opportunities and trade-offs of agriculture and food related interventions. A series of empirical examples were used to illustrate such trade-offs from a gender and social perspective. The analytical categories were applied to the case of conservation agriculture. A range of trade-offs from gender and human development perspectives was identified, which so far have not been sufficiently addressed. Based on this, a series of guiding questions for identifying opportunities and trade-offs related to $\mathrm{CA}$ interventions was elaborated.

The evidence presented suggests that it is critical to address the different needs, preferences and constraints of both male and female farmers in the processes and systems through which nutrition- and climate-smart technologies and interventions are developed, disseminated and promoted.

Figure 2 proposes a conceptual model for pathways to enhance gender and social equity in nutrition- and climatesmart agriculture. The model highlights four key, interrelated components where gender and social equity considerations should be assessed and addressed. It provides suggestions as to how this can be done in relation to the main phases of the project cycle.

Specific solutions regarding particular trade-offs or particular opportunities for strengthening gender and social equity impacts, should be identified and developed together with male and female stakeholders. This can include gender responsive or gender transformative measures as well as involvement of partners having the necessary skills and abilities to address the issues in question and work at the levels where trade-offs occur. It can also involve innovative combinations of technologies whose complementarity can improve tradeoffs. In addition, policy interventions can contribute to the stimulation of inclusive development and the reduction of gender constraints related to specific interventions.

In order to harness technology development and diffusion for positive development impacts, a holistic, gender transformative, farming- and food systems approach is recommended. Yet, to build broad support for mainstreaming such integrated approaches in agricultural research and development projects, further evidence of their potential and specific challenges, is needed.

Acknowledgement The research was conducted under the CGIAR Research Program on Climate Change, Agriculture and Food Security (CCAFS) and the CGIAR Research Program on Maize (MAIZE) by scientists based at the International Maize and Wheat Improvement Center (CIMMYT). Many thanks go to Jon Hellin, Lutz Göhring and Jens Riis for the inspiring discussions and comments as well as to Mike Listman for the great language editing.

Open Access This article is distributed under the terms of the Creative Commons Attribution License which permits any use, distribution, and reproduction in any medium, provided the original author(s) and the source are credited.

\section{References}

Ackerman, F. (2007). The economics of atrazine. International Journal of Occupational and Environmental Health, 13, 441-449.

Alderman, H., Chiappori, P.-A., Haddad, L., Hoddinott, J., \& Kanbur, R. (1995). Unitary versus collective models of the household: Is it time to shift the burden of proof? World Bank Research Observer, 10(1), $1-19$.

Anand, S., \& Sen, A. (2000). Human development and economic sustainability. World Development, 28(12), 2029-2049.

Anderson, M. D. (2008). Rights-based food systems and the goals of food systems reform. Agriculture and Human Values, 25, 593-608.

Badstue, L. B. (2006). Smallholder Seed Practices: Maize Seed Management in the Central Valleys of Oaxaca, Mexico. PhD thesis. Wageningen: Wageningen University.

Baudron, F., H.M. Mwanza, B. Triomphe, \& Bwalya, M. (2007). Conservation Agriculture in Zambia: a Case Study of Southern Province. Nairobi: African Conservation Tillage Network (ACT), Centre de Coopération Internationale de Recherche Agronomique pour le Développment (CIRAD), Food and Agriculture Organization of the United Nations (FAO). 
Baudron, F., Corbeels, M., Monicat, F., \& Giller, K. E. (2009). Cotton expansion and biodiversity loss in African savannahs, opportunities and challenges for conservation agriculture: a review paper based on two case studies. Biodiversity and Conservation, 18(10), 26252644.

Bellon, M. (1996). The dynamics of crop infraspecific diversity: A conceptual framework at the farmer level. Economic Botany, $50(1), 26-39$.

Bellon, M. R., Berthaud, J., Smale, M., Aguirre, A., Taba, S., Aragon, F., Diaz, J., \& Castro, H. (2003). Participatory landrace selection for onfarm conservation: An example from the Central Valleys of Oaxaca, Mexico. Genetic Resources and Crop Evolution, 50, 401-416.

Berti, P. R., Krasevec, J., \& FitzGerald, S. (2004). A review of the effectiveness of agriculture interventions in improving nutrition outcomes. Public Health Nutrition, 7(5), 599-609.

Beuchelt, T. D. (2008). Support Networks of Rural Households. A Case Study of Risk-Management in Northern Vietnam. Kommunikation und Beratung - Sozialwissenschaftliche Schriften zur Landnutzung und ländlichen Entwicklung No. 86. Weikersheim: Margraf Publishers.

Beuchelt, T. D., \& Virchow, D. (2012). Food sovereignty or the human right to adequate food: which concept serves better as international development policy for global hunger and poverty reduction? Agriculture and Human Values, 29(2), 259-273.

Bishop-Sambrook, C., \& Wonani C. (2008). The household approach as an effective tool for gender empowerment: a review of the policy, process and impact of gender mainstreaming in the agricultural support programme in Zambia. http://asp.ramboll.se/Docs/stcs/ GenderStudy.pdf. Accessed 28 January 2013.

CCAFS \& FAO. (2012). Training Guide: Gender and Climate Change Research in Agriculture and Food Security for Rural Development. Rome, IT: FAO.

CGIAR Consortium. (2012). Redressing gender disparities: a transformative approach to our research. http://www.cgiar.org/consortiumnews/redressing-gender-disparities-a-transformative-approach-toour-research/. Accessed 29 January 2013.

Charman, A.J.E. (2008). Empowering Women Through Livelihoods Orientated Agricultural Service Provision. A Consideration of Evidence from Southern Africa. UNU-WIDER Research Paper 01/ 2008. Helsinki: Institute for Development Economics Research (UNU-WIDER).

Cornwall, A., \& Nyamu-Musembi, C. (2004). Putting the "Rights-Bases Approach" to Development into Perspective. Third World Quarterly, 25(8), 1415-1437.

Deere, C.D. (2005). The Feminization of Agriculture? Economic Restructuring in Rural Latin America. Geneva, CH: Occasional Paper No. 1. Geneva: United Nations Research Institute for Social Development (UNRISD).

Derpsch, R., Friedrich, T., Kassam, A., \& Hongwen, L. (2010). Current status of adoption of no-till farming in the world and some of its main benefits. International Journal of Agricultural and Biological Engineering, 3(1), 1-25.

DFID. (1999). Sustainable livelihoods guidance sheets - section 1+2. Department for International Development (DFID). London: Department for International Development (DFID).

Doss, C. R. (2001). Designing agricultural technology for African women farmers: lessons from 25 years of experience. World Development, 29(12), 2075-2092.

Erenstein, O. (2003). Smallholder conservation farming in the tropics and sub-tropics: a guide to the development and dissemination of mulching with crop residues and cover crops. Agriculture, Ecosystems \& Environment, 100(1), 17-37.

Erenstein, O., Sayre, K., Wall, P. C., Hellin, J., \& Dixon, J. (2012). Conservation agriculture in maize- and wheat-based systems in the (sub)tropics: lessons from adaptation initiatives in South Asia, Mexico, and Southern Africa. Journal of Sustainable Agriculture, 36(2), 180-206.
European Commission. (1999). Project Cycle Mangement - Training Handbook. from http://utenti.dea.univpm.it/sotte/Testi ET_file/pcm handbook.pdf. Accessed 22 July 2013.

FAO. (1996). Declaration on world food security. World Food Summit, FAO, Rome. http://www.fao.org/docrep/003/w3613e/w3613e00. HTM. Accessed 21 July 2013.

FAO. (1998). The right to food in theory and practice. Rome: Food and Agriculture Organization (FAO).

FAO. (2010). Gender and Nutrition. http://www.fao.org/docrep/012/ al184e/al184e00.pdf. Accessed 28 January 2013.

FAO. (2011). The state of food and agriculture, 2010-2011. Women in agriculture: Closing the gender gap for development. Rome: Food and Agriculture Organization (FAO).

FAO. (2012). FAO Statistical Yearbook 2012. World Food and Agriculture. Part 3 Feeding the World. http://www.fao.org/docrep/ 015/i2490e/i2490e00.htm. Accessed 21 July 2013.

FAO. (2013). The state of food and agriculture. Food systems for better nutrition. Rome: Food and Agriculture Organization (FAO).

FAO, WFP, \& IFAD. (2012). The State of Food Insecurity in the World 2012. Economic growth is necessary but not sufficient to accelerate reduction of hunger and malnutrition. Rome: Food and Agriculture Organization (FAO).

Fischer, I., Beuchelt, T. D., Dufhues, T., \& Buchenrieder, G. (2010). RiskManagement networks of ethnic minorities in Vietnam. Asia-Pacific Development Journal, 17(2), 93-118.

Friis-Hansen, E., Duveskog, D., \& Taylor, E. W. (2012). Less noise in the household : the impact of Farmer Field Schools on Gender Relations. Journal of Research in Peace, Gender and Development, 2(2), 44-55.

Giller, K. E., Witter, E., Corbeels, M., \& Tittonell, P. (2009). Conservation agriculture and smallholder farming in Africa: The heretics' view. Field Crops Research, 114(1), 23-34.

Govaerts, B., Sayre, K. D., \& Deckers, J. (2005). Stable high yields with zero tillage and permanent bed planting? Field Crops Research, 94(1), 33-42.

Govaerts, B., Sayre, K. D., Goudeseune, B., De Corte, P., Lichter, K., Dendooven, L., \& Deckers, J. (2009). Conservation agriculture as a sustainable option for the central Mexican highlands. Soil and Tillage Research, 103(2), 222-230.

Hayes, T. B., Anderson, L. L., Beasley, V. R., de Solla, S. R., Iguchi, T., Ingraham, H., Kestemont, P., Kniewald, J., Kniewald, Z., Langlois, V. S., Luque, E. H., McCoy, K. A., Muñoz-de-Toro, M., Oka, T., Oliveira, C. A., Orton, F., Ruby, S., Suzawa, M., Tavera-Mendoza, L. E., Trudeau, V. L., Victor-Costa, A. B., \& Willingham, E. (2011). Demasculinization and feminization of male gonads by atrazine: consistent effects across vertebrate classes. The Journal of Steroid Biochemistry and Molecular Biology, 127(1-2), 64-73.

Hellin, J., Keleman, A., \& Bellon, M. (2010). Maize diversity and gender: research from Mexico. Gender and Development, 18(3), 427-437.

Hellin, J., Erenstein, O., Beuchelt, T., Camacho, C., \& Flores, D. (2013). Maize stover use and sustainable crop production in mixed croplivestock systems in Mexico. Field Crops Research. doi:10.1016/j. fcr.2013.05.014.

Hobbs, P. R. (2007). Conservation agriculture: What is it and why is it important for future sustainable food production? Journal of Agricultural Science, 145(2), 127-137.

Hobbs, P. R., Sayre, K., \& Gupta, R. (2008). The role of conservation agriculture in sustainable agriculture. Philosophical transactions of the Royal Society of London. Series B, Biological sciences, 363(1491), 543-55.

ISPC. (2013). CGIAR System-Level Outcomes (SLOs), their impact pathways and inter-linkages. ISPC white paper. Independent Science \& Partnership Council, CGIAR. http://www. sciencecouncil.cgiar.org/fileadmin/templates/ispc/Expert_advice/ Advice to the CGIAR/White Paper on SLO Linkages and Impact_Pathways.pdf. Accessed 21 July 2013. 
Kassam, A., Friedrich, T., Shaxson, F., \& Pretty, J. (2009). The spread of Conservation Agriculture: justification, sustainability and uptake. International Journal of Agricultural Sustainability, 7(4), 292-320.

Kettles, M. K., Browning, S. R., Prince, T. S., \& Horstman, S. W. (1997). Triazine herbicide exposure and breast cancer incidence: an ecologic study of Kentucky counties. Environmental Health Perspectives, 105(11), 1222-1227.

Klos, S. (2000). Lessons learned from the Gender Oriented Participatory Extension Approach (GPEA) in Zambia. Newsletter of the emerging platform on services within Division "Rural Development" (45) of gtz (4): 20-23.

Knowler, D., \& Bradshaw, B. (2007). Farmers' adoption of conservation agriculture: A review and synthesis of recent research. Food Policy, 32(1), 25-48.

Kürschner, E., Arnold, I., Güllemann, H., Kupfer, G., Manje, B., \& Wils, O. (2000). Incorporating HIV/AIDS Concerns into Participatory Rural Extension. Weikersheim: Margraf Publishers, SLE Seminar für Ländliche Entwicklung/Centre for Advanced Training in Rural Development.

Lemke, S., \& Bellows, A. C. (2011). Bridging Nutrition and Agriculture: Local Food-Livelihood Systems and Food Governance Integrating a Gender Perspective. Technikfolgenabschaetzung - Theorie und Praxis, 20(2), 52-60.

Meinzen-Dick, R., A.R. Quisumbing, J. Behrman, P. Biermayr-Jenzano, V. Wilde, M. Noordeloos, C. Ragasa, \& Beintema, N. (2011). Engendering Agricultural Research, Development, and Extension. Washington, D.C.: International Food Policy Research Institute (IFPRI).

Milder, J.C., T. Majanen, \& Scherr, S.J. (2011). Performance and Potential of Conservation Agriculture for Climate Change Adaptation and Mitigation in Sub-Saharan Africa. http://www. foodgrainsbank.ca/uploads/CARE-WWF-EcoAgriculture_ Conservation Agriculture in Sub-Saharan Africa FINAL REPORT 2011-02-2811.pdf. Accessed 9 December $201 \overline{2}$.

Momsen, J. H. (2010). Gender and Development (2nd ed.). London and New York: Routledge.

Moser, C. O. (1993). Gender Planning and Development: Theory, Practice \& Training. London and New York: Routledge.

Nyanga, P. H., Johnsen, F. H., \& Kalinda, T. H. (2012). Gendered Impacts of Conservation Agriculture and Paradox of Herbicide Use Among Smallholder Farmers. International Journal of Technology and Development Studies, 3(1), 1-24.

Paris, T. R., \& Chi, T. T. N. (2005). The Impact of Row Seeder Technology on Women Labor: A Case Study in the Mekong Delta, Vietnam. Gender, Technology and Development, 9(2), 157184.

Paris, T.R., \& Pingali, P.L. (1996). Do agricultural technologies help or hurt poor women? Competition and conflict in Asian agricultural resource management: Issues, Options, and Analytical Paradigms: IRRI Discussion Paper Series No. 11, pp. 237-245. Los Banos, Lagun: International Rice Research Institute (IRRI).

Ponniah, A., R. Puskur, S. Workneh, \& Hoekstra, D. (2008). Concepts and Practices in Agricultural Extension in Developing Countries: A Source Book. Washington, D.C.: International Food Policy Research Institute (IFPRI) and Nairobi: International Livestock Research Institute (ILRI).
Quisumbing, A.R., \& Maluccio, J.A. (2000). Intrahousehold allocation and gender relations : new empirical evidence from four developing countries. FCND Discussion Paper No. 84. Washington, D.C.: International Food Policy Research Institute (IFPRI).

Rae, I. (2008). Women and the Right to Food. International Law and State Practice. Right to Food Studies. Rome: Food and Agriculture Organization (FAO).

Ramírez-López, A., Beuchelt, T. D., \& Velasco-Misael, M. (2013). Factores de adopción y abandono del sistema de agricultura de conservación en los Valles Altos de México [Factors for adoption and abandonment of conservation agriculture systems in the high valleys of Mexico]. Agricultura, Sociedad, y Desarrollo, 10(2), 195-214.

Sanchís, J., Kantiani, L., Llorca, M., Rubio, F., Ginebreda, A., Fraile, J., Garrido, T., \& Farré, M. (2012). Determination of glyphosate in groundwater samples using an ultrasensitive immunoassay and confirmation by on-line solid-phase extraction followed by liquid chromatography coupled to tandem mass spectrometry. Analytical and Bioanalytical Chemistry, 402(7), 2335-45.

Socorro Diokno, M. (2013). Human rights based approach Development planning toolkit. http://www.hrbatoolkit.org/. Accessed 21 July 2013.

Swaminathan, M.S. (2012). Nutrition Sensitive Agriculture. Paper prepared for the Second International Conference on Nutrition (ICN+20). http://www.globalfoodsecurityforum.com/2012/lang/ content en/downloads/my-documents/interesting-paper/NutritionSensitve-Agri-ICN+20-Brian-Thompson-FAO.pdf. Accessed 17 June 2013

UN-CESCR. (1999). Substantive issues arising in the implementation of the International Covenant on Economic, Social and Cultural Rights. General Comment 12: The right to adequate food (Art. 11). New York: United Nations-Economic and Social Council. http://www. unhchr.ch/tbs/doc.nsf/0/3d02758c707031d58025677f003b73b9. Accessed 21 July 2013

UNICEF. (2011). Promoting Gender Equality: An Equity-Focused Approach to Programming. New York: United Nations Children's Fund (UNICEF).

USAID \& IGWG. (2011). A Summary Report of New Evidence that Gender Perspectives Improve Reproductive Health Outcomes. Washington, D.C: USAID and The Interagency Gender Working Group (IGWG).

Valbuena, D., Erenstein, O., Homann-Kee Tui, S., Abdoulaye, T., Claessens, L., Duncan, A. J., Gérard, B., Rufino, M. C., Teufel, N., van Rooyen, A., \& van Wijk, M. T. (2012). Conservation agriculture in mixed crop-livestock systems: Scoping crop residue trade-offs in Sub-Saharan Africa and South Asia. Field Crops Research, 132, 175-184.

Wall, P. C. (2007). Tailoring conservation agriculture to the needs of small farmers in developing countries: An analysis of issues. Journal of Crop Improvement, 19(1-2), 137-155.

WCED. (1987). Our Common Future - The "Brundtland Report". Oxford: Oxford University Press.

World Bank. (2007). From Agriculture to Nutrition: Pathways, Synergies and Outcomes. Washington, D.C.: World Bank.

World Bank. (2009). Gender in Agriculture Sourcebook. Washington, D.C.: World Bank. 


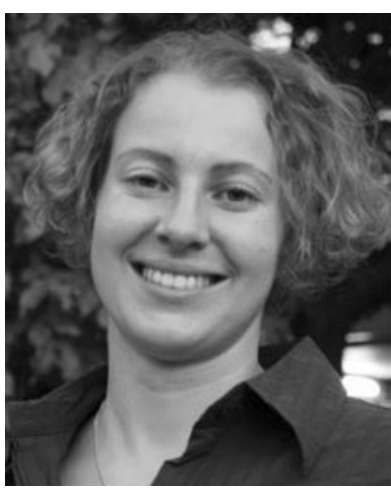

Tina D Beuchelt $\mathrm{PhD}$, is an agricultural economist and development specialist working at the International Maize and Wheat Improvement Center (CIMMYT). She is involved in projects related to sustainable agricultural intensification, food security, gender and climate change in Latin-America, Africa and Asia. Her research interests include food security, rural development processes and policies, gender and social equity, socio-economic aspects of sustainable agricultural technologies and their diffusion in the context of global social, economic and environmental changes, human rights as well as standards and certifications.

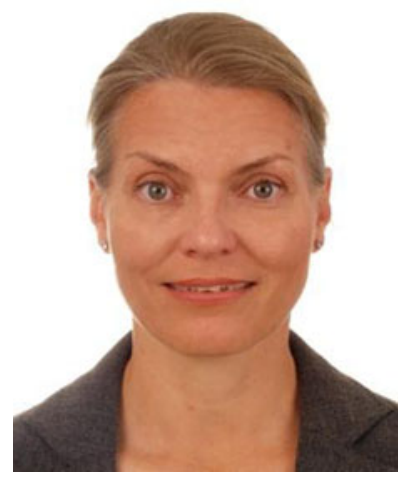

Lone Badstue $\mathrm{PhD}$, is a Rural Development Sociologist with broad experience working with different types of social actors and multi-disciplinary teams on issues related to rural development processes, including social relations and gender, local livelihoods and farmer decision making processes, seed systems and crop genetic resources, technology diffusion, natural resource management and collective action. 